\section{Shear behaviour of silicate-based structural adhesives for timber}

\author{
DÁNIEL CSANÁDY - BME, Department of Construction Materials and Technologies \\ - csanady.daniel@emk.bme.hu \\ OLIVÉR FENYVESI - BME, Department of Construction Materials and Technologies \\ - fenyvesi.oliver@emk.bme.hu
}

Érkezett: 2021. 01. 28. " Received: 28. 01. 2021. - https://doi.org/10.14382/epitoanyag-jsbcm.2021.12

\section{Abstract}

In timber structures, many joints are constructed with polymer adhesives and industrial timber by-products also contain polymer resins in huge amount. Majority of these adhesives are artificial polymers with big environmental footprints and lots of them have a negative effect on human health. Some natural or silicate-based adhesives are available in the construction industry, but their heat or water resistance are poor. Some of these types of adhesives have evolved but compounds contain some artificial polymer, and the heat resistance is worse than silicate-based in general. In this article, water-resistance and heat resistance have been investigated in the case of silicate-based binders. In order to be a benchmark, a PVA based industrial timber adhesive (as reference) was also tested. The shear strength of the bonded joints was tested and compared under wet and hot conditions. Reference silicate-based binder was modified with other silicate, acids or alkalines. The effect of modifiers on the solubility of binders was also investigated.

As a result it was stated, that reference binder has a higher strength under normal conditions, but the modified silicate binders have better performance under wet and hot conditions. The modifiers can increase the shear strength, ductility, and water-resistance without decreasing the heat resistance and also makes the material quality more uniform. The silicate binders make a rough bond surface, which can pass the forces effectively between the components of specimens. Keywords: shear behaviour, adhesives for timber, timber joints

Kulcsszavak: nyírószilárdsági viselkedés, faragasztó, ragasztott fakapcsolatok
\end{abstract}

Dániel CSANÁDY

Civil engineer $k$ (BME 2017), PhD candidate, Department of Construction Materials and Technologi. Member of Hungarian Scientific Association of Silicate Industry. Main areas of interest: reaction to fire of building materials, development of new generation concretes and silicate binders, environmentally friendly building materials, biomimetics, thermal insulation, sound insulation, development of building materials.

Dr. Olivér FENYVESI Civil engineer MSC (BME 2005), PhD (BME 2012), Specialized Engineer in Preservation of Building Heritage (BME 2017), Specialized Engineer in Corrosion (HCE 2018), assistant professor in BME, Department of Construction Materials and Technologies. Main research fields: early age shrinkage cracking in normal and ghtweight concretes, fibre reinforced concretes, LWAC, building diagnostics, preservation of building heritage. Secretary of the Concrete Division and member of Stone and Aggregates Division of the Hungarian Scientific Association of Silicate Industry, member of the Hungarian Group of fib (International Federation fo Structural Concrete), member of ACl (American Concrete Institute), member of the Hungarian Chamber of Engineers.

\section{Research motivation}

The application of timber in structures has revived in recent decades, as a result of which the amount of adhesive/binder used has increased. Most of these adhesives are high environment polluting, so the present research is concerned with developing a sustainable alternative. During the technological development of the nineteenth century, timber lost its leading role in the construction industry, and modern building materials, such as concrete and steel became dominant. Due to the extensive use of natural resources and the significant demand for invested energy, the construction industry has a huge environmental footprint today. In Europe today, the construction industry responsible for around $42 \%$ of total energy consumption generates $35 \%$ of total greenhouse gas emissions. Over the past two decades, the growing awareness of policymakers and society about the depletion of natural resources and climate change has had a strong impact on the construction industry, leading to an increase in the demand for sustainable and renewable building materials [1]. Wood is the best known renewable building material. Therefore, it has become important again, which has helped develop a new bond (glueing) technologies. This is well illustrated by the fact that the use of plywood in Europe almost doubled between 2007 and 2012 and is expected to increase further in the future [2] (Fig. 1).

Nowadays, the sustainable lifestyle, green thinking is dominant in all areas of life. As a result, many researches have been conducted to create possible, environmentally friendly alternatives to common adhesives. More than $70 \%$ of wood products are made with some kind of glued technology [3].
Wood adhesives have a significant share of the amount of adhesive used in the world. It is of paramount importance to reduce the amount of formaldehyde-containing adhesives used, which is currently used in the largest quantities to bond fibreboard and other by-product based boards (Fig. 1). The modern adhesive industry initially used large amounts of formaldehyde in almost all adhesives, which can significantly damage the health of workers, so the development of lower formaldehyde and formaldehyde-free adhesives began. Although modern adhesives are less harmful than their predecessors, in case most of them are worth using masks and skin and eye protection. In addition, their production is energy-intensive (mostly fossil-based) and produces large amounts of waste both during production and during use, which is currently difficult to dispose or recycle [4].

Environmentally conscious adhesives were initially made from natural polymers of plants and animals, animal blood, skin, casein, starch, soybeans, dextrin, or cellulose. However, they provided a weaker bond than synthetic adhesives and had low water and fire resistance. The growing interest in biopolymers from renewable sources such as wood, corn, and cereals has encouraged the $\mathrm{R} \& \mathrm{D}$ sector, for example, to use biopolymers as a sustainable adhesive [6]. Inorganic adhesives can have a similarly positive effect on reducing the environmental pollution in the same way as natural-based adhesives. The laboratory research section of this article deals with such inorganic adhesives. In the next chapter, the main classes of adhesives, the most important components and basic properties of these classes are briefly described and characterised. 

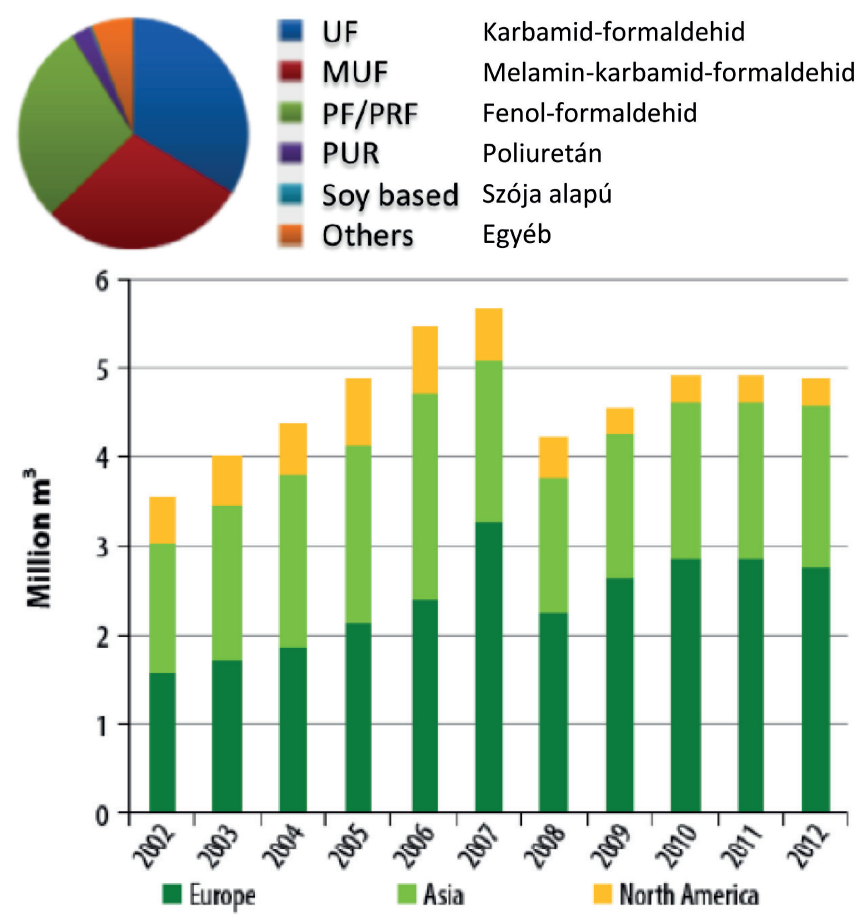

Fig. 1 Global market share of various adhesives [5] (above), Global consumption of plywood in recent years [2] (below)

1. ábra A különféle faragasztók globális piaci részesedése [5] (fent). A globális rétegelt ragasztott lemez felhasználás az elmúlt években [2] (lent)

\section{Organic adhesives for the timber industry}

Urea-formaldehyde was the first widespread synthetic adhesive introduced in the 1930s. Synthetic glue has resulted in rapid growth in the timber industry [7]. Subsequently, new synthetic adhesives for various special applications (not only for timber gluing) were continuously developed, and proven adhesives were further developed [8][9]. Synthetic adhesives fall into two categories: thermoplastics and thermosets. The two types differ in their chemical structure (linear and crosslinked polymers) [10].

\subsection{Thermosetting adhesives}

The setting (crosslinking) of thermosetting adhesives is an irreversible process. The curing process can be catalysed in most cases by an exothermic process and the introduction of external energy (heat, light) or chemicals (catalyst materials). The reaction results in a higher molecular weight and melting point. These adhesives provide a stronger bond than thermoplastics and are more resistant to thermal, mechanical and chemical effects. Thermosetting adhesives are often used to bond structural timber elements [11].

\subsubsection{Dispersions based on polyvinyl acetate}

The most common plastic-based adhesive is polyvinyl acetate. Most are white, viscous, water-based dispersions containing polyvinyl alcohol (PVA) as a protective colloid. After evaporation of the water, these types of plastic adhesives form a flexible film on the surface with good light resistance (UV) and durability. The film layer is sensitive to water, swells, decreases in strength, does not dissolve but regains a significant part of its strength after drying. Their advantage is that they show good compatibility with starch and gluten glues. As the temperature increases, their viscosity decreases, leading to incomplete film formation in porous materials. At low temperatures, the viscosity increases, which can cause bonding problems and prolong the setting time of the adhesive [12]. In the present study, polyvinyl acetate based adhesive was used as a reference to compare the test results.

\subsubsection{Polyurethane adhesives}

The advent of polyurethane-based (PUR) adhesives has been a major step forward. Due to their isocyanate content, they are sensitive to humidity and ambient temperature changes, and their use requires stable environmental parameters. These environmental parameters affect the setting time of the adhesive and the reactivity of the components, and thus also the properties of the crosslinked adhesive. Its crosslinking is initiated by the moisture content of the glued timber in the case of onecomponent glue, but there are also two-component variants. It is mainly used for plywood. Total solidification time is about 1-2 days. This type of bonding can ensure the highest load-bearing connections in the case of crosslinked synthetic resins [13].

\subsubsection{Phenol formaldehyde}

Phenol formaldehyde is used in a wide range of timber products. It bonds very well to timber and can be made of heavy-duty and durable contact even in dry and wet conditions. It is mainly used for products exposed to moisture and other weather conditions (chipboard or fibreboard, plywood, pressed laminated timber). Crosslinking is possible both hot and cold, in hot conditions without an initiator. In the cold, it crosslinks with the addition of initiator. Toxic, skin contact should be avoided, free skin should be protected during use, and a mask should be worn.

\subsection{Thermoplastic adhesives}

Their advantage is that the load-bearing bond is formed very quickly between the adhesive and the connected parts, significantly influenced by the instantaneous temperature of the glued elements. In the case of thermoplastic adhesives, the process of melting (plasticisation) and curing is reversible and can be repeated several times [15]. These adhesives are ideally suited for manufacturing technologies where high production speeds and early adhesion are particularly important, such as in the coating of the edges of timber products. Their main disadvantage is the limited thermal resistance, even a small temperature rise can significantly reduce the load-bearing capacity of the adhesive [16]. Their scope is limited, they cannot be applied to structural elements because they are not resistant to heat or fire. Thermoplastic adhesives are not used in timber construction. Therefore they are not relevant to the current dissertation topic, but they are closely related to timber as a material. [15]

\section{Inorganic adhesives for the timber industry}

Inorganic adhesives are based in most cases on the following compounds: sodium silicate, magnesium oxide chloride, lead oxide (litharide), sulphur and various metal phosphates. These materials form strong, though rigid bonds and are well suited for 
special conditions such as high temperatures, in which case they continue to be widely used. Increased use of synthetic organic polymer adhesives has resulted in a reduction in inorganic adhesives [17]. Nowadays, research on inorganic adhesives and organic-inorganic adhesive mixtures has come to the fore again, as it is generally true that the production of these adhesives and the waste generated from them are less harmful to the environment.

Water glass (aqueous sodium or potassium silicate) has long been used as a reliable, inexpensive adhesive for bonding various porous surfaces and materials such as paper, soil, mineral wool, and timber. Water glass is a colourless, odourless, non-flammable, highly alkaline, yet safe liquid. It's disadvantages are the hardened water glass is inelastic, and its water resistance is very poor. Zhang et al. studied the effect of polyvinyl alcohol (PVA) on the water glass. The adhesion, water and fire resistance of the adhesive made by mixing the two materials were investigated. Adhesion and water resistance have been shown to increase, but heat resistance decreases compared to pure water glass [18]. Peng et al. studied the properties of an adhesive/surface treatment agent made from a mixture of water glass and starch and found that the water resistance and flexibility of the mixture increased [19].

\section{Force transfer in bonded connections}

Timber is an anisotropic, porous material. Its cell cavities and dimples are large enough to provide a good way for liquid adhesives to penetrate. The adhesive penetration significantly influences the adhesion/bond of the glued timber elements into the pore system and the proportion of the open pores on the glued surface. [20] (Fig. 2). At this surface, the stresses in the bonded joints are transferred from the adhesive to the bonded base surface. If this is not just the result of adhesion but also a mechanical bond, the resulting bond will have higher strength.

These two components mainly determine the strength of bonded joints: the first is the internal strength of the bonded base material and the internal strength of the binder, so the cohesion and the second is the force acting at the interface of the base material and binder, this is the adhesion. In some cases, the mechanical interlock is also acting. In a good quality bonded joint, the adhesive forces are at least as high as the cohesive forces. This means, that when well-bonded pieces of material are subjected to a large force, the failure (tearing, breaking) occurs inside bonded material and not at the interface due to the separation of the binder [21]. With this simple model, the process of force transfer is more complicated in reality, and the layers of the connection cannot be so clearly divided. They can be divided into the following layers, which are chain-linked to each other (Fig. 2).
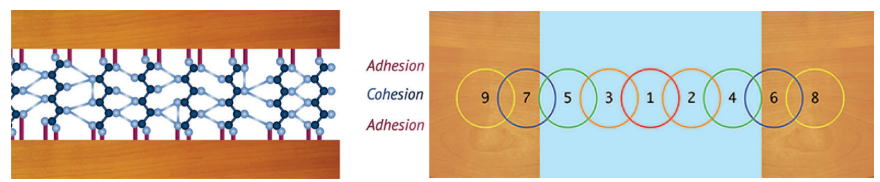

Fig. 2 Adhesion and cohesive forces in bonded timber joints (left) Chain analogy in force transfer of glued timber joints (right) [22]

2. ábra Adhéziós és a kohéziós erők müködése a ragasztott fakapcsolatokban (balra) Lánc analógia ragasztott fakapcsolatok eröátadódásában (jobbra) [22]
1: Pure binder phase, which is not affected by the bonded base surface;

2-3: transition layer of binder no longer completely homogeneous affected by bonded base surface;

4-5: A boundary layer between the binder and the bonded surface, which ensures adhesion between the different materials, thus ensuring the connection by covalent or secondary chemical bonds;

6-7: In this layer, the binder enters in the surface pores and thus influences the properties of the base material, as well as provides mechanical interlock (Fig. 3) [3].

8-9: Pure timber material where glue does not enter
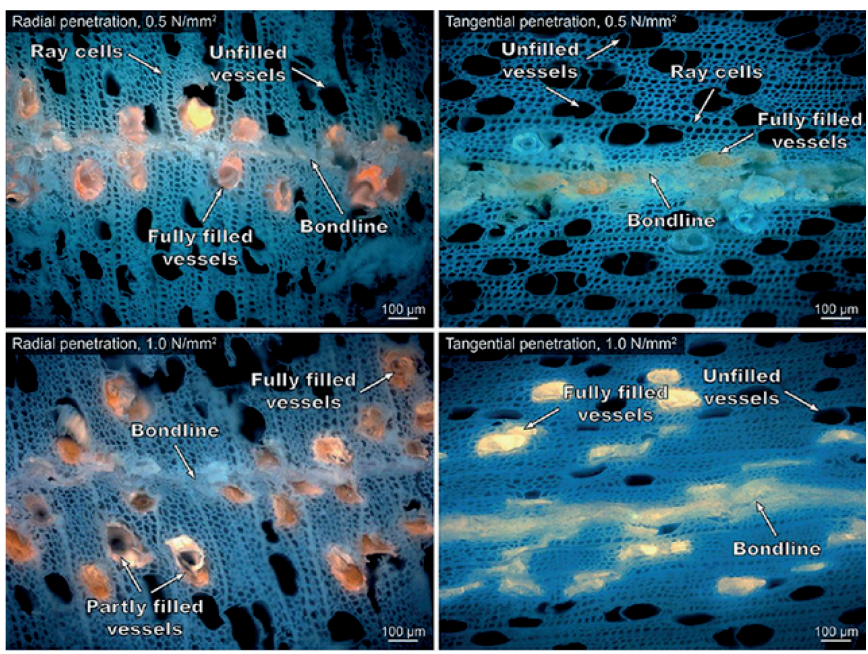

Fig. 3 The significance of adhesives penetrating the timber pore system. Lower strength at lower penetration (left), higher strength at higher penetration (right) [23]

3. ábra Faragasztók behatolása az anyag pórusrendszerébe. Kisebb szilárdság kisebb behatolás (balra), nagyobb szilárdság nagyobb behatolás (jobbra) [23]

\section{Research objectives}

Organic polymer-based adhesives have a high environmental impact, limited heat resistance and in many cases water/ vapour resistance. Silicate-based adhesives have better thermal-resistance, but their performance under normal use generally lags behind organic polymers and is mostly sensitive to moisture. A basic goal is to select a silicate raw material that can be well developed and modified to improve the adhesive properties to approach the favourable properties of organic polymeric adhesives. The main goal is to increase moisture resistance and at least retention of thermal resistance. The developed binder is primarily recommended for bonding timber joints exposed to high temperatures.

\section{Laboratory research}

\subsection{Materials}

The adhesive-bonded specimens were made according to ASTM D906 and were $100 \mathrm{~mm}$ long, $25 \mathrm{~mm}$ wide, $4 \mathrm{~mm}$ thick, from C20 material class pine wood. The bonded connection was made on a surface with a nominal size of $30 \mathrm{~mm} \times 25 \mathrm{~mm}$ for each specimen. The bonded surfaces of the specimens were ground to an absolute plane due to the proper connection of the bonded elements, and then the surfaces were dusted with 
high-pressure air. Each element was dried to constant weight at $60{ }^{\circ} \mathrm{C}$ in a drying oven before applying the binder.

A polyvinyl-acetate (Water resistance class D3 according to EN 205 [24]) adhesive was used for the reference specimens. The newly developed inorganic binder studied in this article was based on potassium silicate (signed as B1). To increase the binder strength and water resistance of this material, silicate derivatives (B2-B3) and acids or alkalis (B4-B6) were also used as additional materials to improve the properties of the binder. Among the modified silicate binder, B1-B5 are onecomponent, B6 is a two-component binder. The binders were applied in equal mass to each contact surface. It is important to note that after an initial pressing of 5-10 seconds, the B6 binder already had a minimum strength (i.e., crosslinking begins), in contrast to the other silicate-based binders tested.

To ensure that the load line passes through the adhesive layer and the centreline of the specimen, we checked the parallelism of the connected elements and marked the central axis of the elements so that it coincided with the central axis of the clamping jaws. Thus, all other possible stresses were excluded, the connection was loaded by pure shear stress (Fig. 4). The applied load was displacement controlled at a speed of $1 \mathrm{~mm} /$ min. The research matrix is summarised in Table 1.

\begin{tabular}{cccccc} 
Component & $\begin{array}{c}\text { Organic/ } \\
\text { Inorganic }\end{array}$ & $\begin{array}{c}\text { Modifying } \\
\text { agent }\end{array}$ & \multicolumn{3}{c}{ Test condition } \\
normal & wet & high temp. \\
\hline 1 & organic & - & $x$ & $x$ & $x$ \\
\hline 1 & inorganic & - & $x$ & - & $x$ \\
\hline 1 & inorganic & x & x & x & x \\
\hline 1 & inorganic & $x$ & $x$ & $x$ & $x$ \\
\hline 1 & inorganic & $x$ & $x$ & $x$ & $x$ \\
\hline 2 & inorganic & $x$ & $x$ & $x$ & $x$
\end{tabular}

Table 1 Research matrix

1. táblázat A kutatás kísérleti mátrixa

\subsection{Test methods}

\subsubsection{Test under normal conditions}

The bonded surfaces were designed according to ASTM D906 and, the reference adhesive was applied on specimens according to application instructions, left in laboratory air for the full cure time ( 24 hours) and then for 24 hours to ensure the same age of the different adhesives at the time of shear strength test. The specimens made by the silicate-based binder were cured in a $60{ }^{\circ} \mathrm{C}$ oven for 24 hours and then kept in laboratory air for 24 hours to be tested at the same moisture content as the reference adhesive.

\subsubsection{Test under moisture load}

B2 and B6 binder were tested under moisture load, as they performed best among silicate-based binders in the normal conditions test. In this case, the procedure was performed according to ASTM D-906 and D-1183too, the specimen was soaked in water at $24{ }^{\circ} \mathrm{C}$ for 48 hours, and then the shear test was performed in wet condition. The boiling test required by the standard was not performed because it is less relevant to the conditions of use.
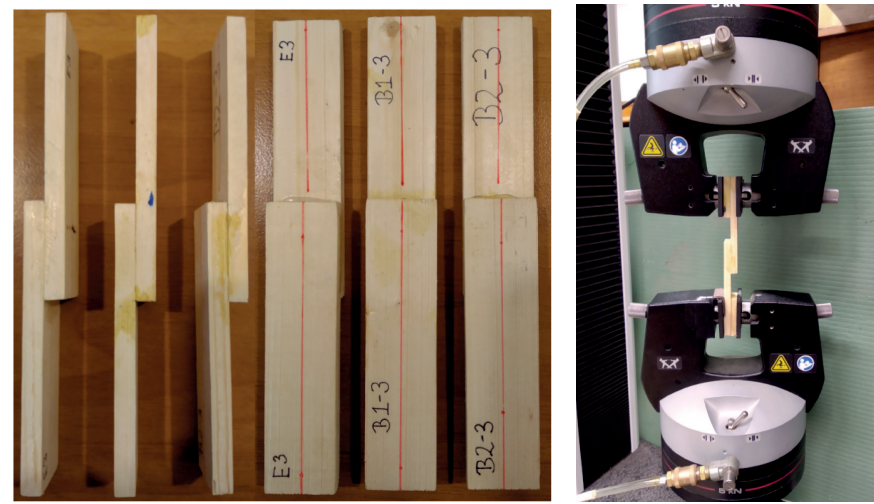

Fig. 4 Bonded specimens (left) and shear test (right)

4. ábra A ragasztott próbatestek kialakitása (balra) és a nyíróvizsgálat (jobbra)

In the case of silicate-based adhesives, water resistance is a common problem. It is an important parameter, so the water solubility of pure water glass was compared with the solubility of the modified silicate binder that achieved the best results in mechanical tests. A non-standard method was used for the study. For both types of binders tested, the same weight of waterglass was weighed into the formworks in every series (the water glass component was the same), so in the case of water glass mixed with silicate additive, the additive weight appeared as a surplus. This was necessary because it would distort the change in solubility of the base material if the weight of the additional material and its solubility were taken into account. The specimens were thin cylindrical plates with the same diameter and were tested by complete immersion in water. The specimens were dried to constant mass before and after the dissolution test, and the constant mass was reached at the same time for all specimens due to the initial same water content. The samples were submerged in silicone formworks (Fig. 5). The specimens were dissolved in distilled water. A quantity of water (water glass: water; 1:5) determined by the mass of dried water glass, so that any water saturation affected the results of the tests in the same way (the solution did not reach the saturated state in either case).

After drying, the mass of each specimen was weighted (on an analytical scales) and its integrity was visually inspected at the end of the dissolution cycle. Cycles were continued by type until the particular sample have its integrity, so did not disintegrate. The dissolution cycles were five hours long. Because silicate-based binders are sensitive to water, they can usually appear as an inner structural element.

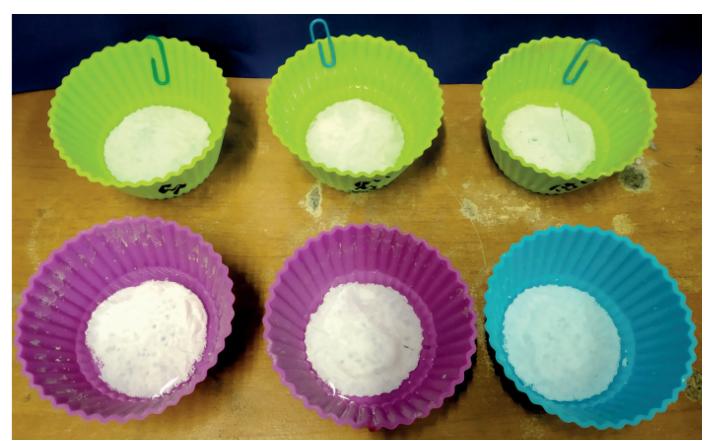

Fig. 5 Parallel solubility test for adhesives B1 and B2

5. ábra Párhuzamos oldhatósági vizsgálat a B1 és B2 jelü ragasztók esetén 

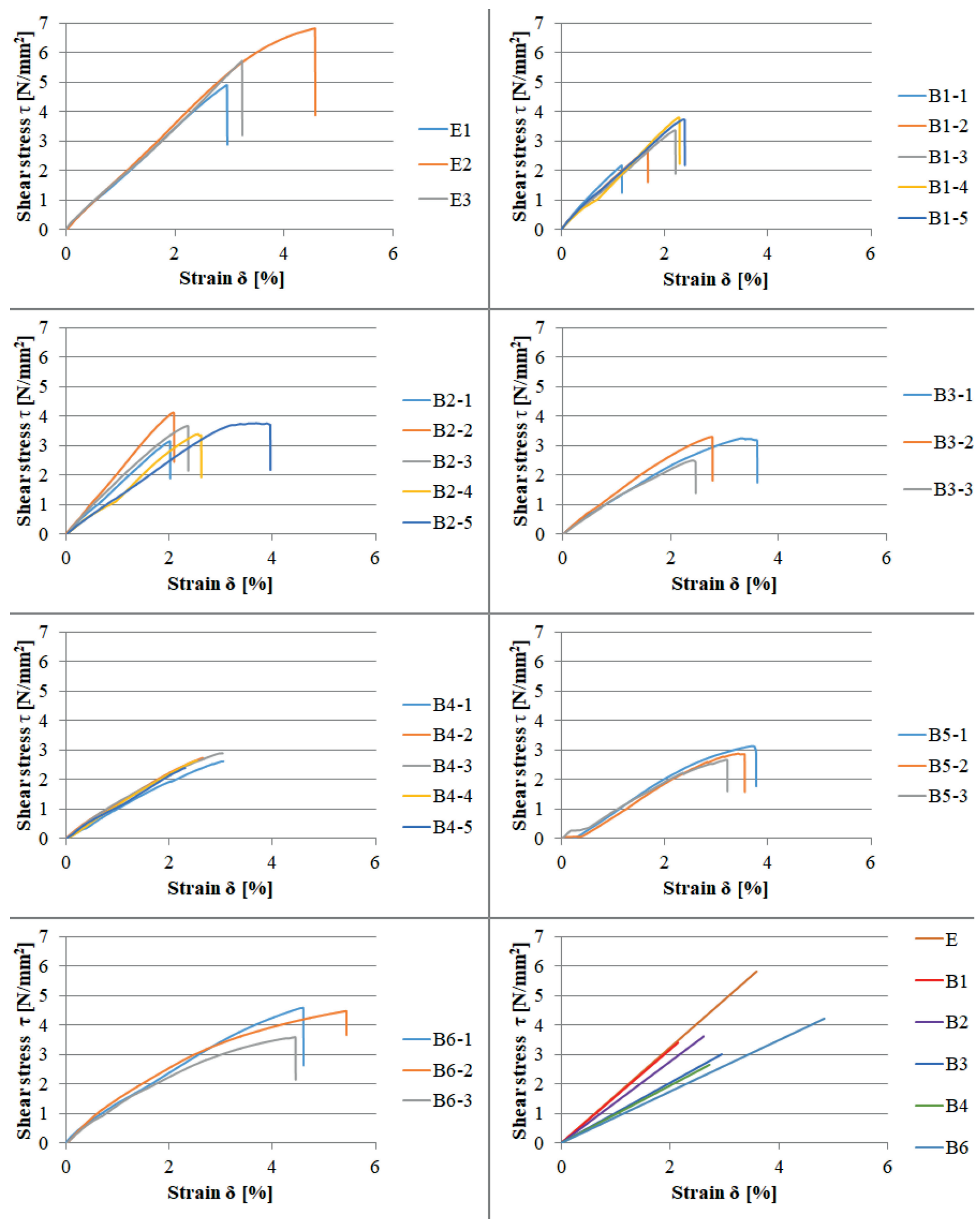

Fig. $6 \tau$ - $\delta$ diagrams of the connections with the tested binders in the case of air-dry condition and normal temperature. Approximation of the average results of the tested binders with a linear diagram of $\tau-\delta$ (bottom right)

6. ábra A vizsgált ragasztókkal készitett kapcsolatok $\tau$ - $\delta$ diagramjai légszáraz, normál hömérsékletü esetben és a vizsgált ragasztók átlageredményeinek közelítése lineáris $\tau$ - $\delta$ diagrammal (jobbra lent) 
In this situation, water can only reach the inner structural elements in extreme situations, such as excessive leaking. In Hungary, the duration of such precipitation can be between 15 and 30 hours a month, so if such precipitation occurs weekly, the bonded structural contact may be exposed to moisture for approximately 5 hours [25] [24][23]. Although in case of leaking "flowing" water loads the bonded joint, which can carry away the solution, with the weight ratio used and the potential for moisture exposure, the method used is quasi-equivalent to common environmental exposure.

\subsubsection{Test under heat load}

In this case, the reference, B2 and B6 binders were tested too. The shear specimens were tested according to ASTM D-233998 [26], so the specimens were kept at $105^{\circ} \mathrm{C}$ for 6 hours and then tested in a heated condition. The specimens were kept at the appropriate temperature by being transferred from the furnace to the loading equipment as short as possible and insulating the loaded cross-section and its surroundings with loose $\left(40 \mathrm{~kg} / \mathrm{m}^{3}\right)$ mineral wool $105^{\circ} \mathrm{C}$.

\section{Research results}

\subsection{Shear strength}

\subsubsection{Air dry, normal temperature case}

The shear behaviour of all joints with the tested binder types can be modelled by a linearly elastic-perfectly rigid material model. Thus, the deformation-stress curves for the specimens can be properly approximated by linear lines, simplifying the averaging of the deformation-stress curves belongs to different adhesive types, and making their comparability illustrative (Fig. 6). The $\tau-\delta$ curves for each binder are shown in Fig. 6. The highest shear stress results were achieved with the E (reference) binder as expected. Interestingly, in the case of B2 binder, the tensile strength and ductility were also increased compared to the adhesive B1 (pure waterglass). Although in most cases, the strength and ductility are inversely proportional to each other, which can be seen in the conventional types of investigated binders. In the case of binder B2, two-thirds of the strength of the reference binder was achieved. Although the best results were found by binder $\mathrm{E}$, the failure occurs inside the timber in only one case, other cases on the bonded surface. This means the failure mode was not ideal in the case of the reference adhesive.

The explanation for this was verified by the bonded crosssection records (cut and polished) by scanning electron microscopy (Fig. 7). The section was made perpendicular to the direction of loading of the specimen (due to better sample preparation). Still, it can be assumed that the connection structure is also very similar in the parallel direction.

Silicate adhesives are more rigid, so they are more sensitive to tensile and shear loads than organic adhesives. On the other hand, their stiffness is higher than the timber specimens, so the stresses increase due to minor deformations in the bonded cross-section. Therefore, in general, the failure occurs in the glue cross-section or on the contact surface. Worthy of note again that in most tested silicate binders, the failure did not occur purely at the bonding contact surface, but partly inside the timber cross-section. It can be seen that in the case of the pure water glass adhesive B1, the failure occurred in the cross-section of the binder (Fig. 8), in contrast, in most of the modified binders B2-B6 the failure was partially in the timber cross-section (Fig. 8). In the B6 binder case, the complete failure typically occurred in the timber material (Fig. 9).

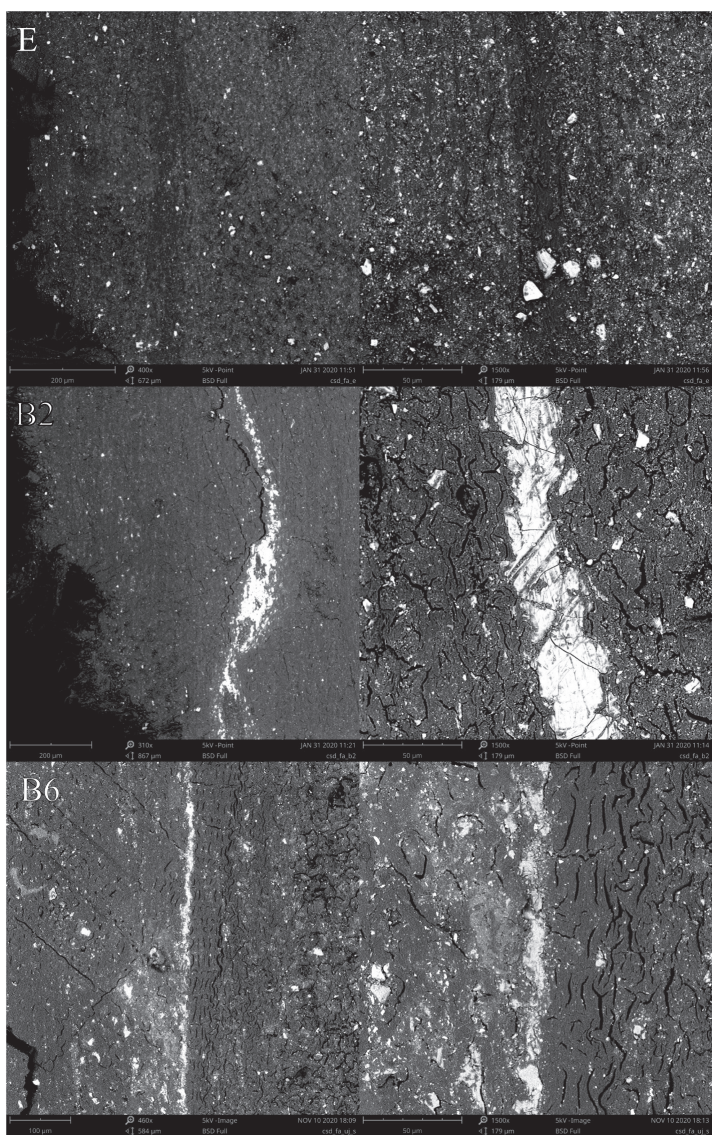

Fig. 7 Typical cross-sectional view of E, B2 and B6 (top to down) adhesive joints after crack failure at 400 and 1500 magnification

7. ábra Az E, B2 és a B6 (fentről lefelé) ragasztóval készült kapcsolatok jellemzó keresztmetszeti képe tönkremenetel után 400- és 1500-szoros nagyitásban

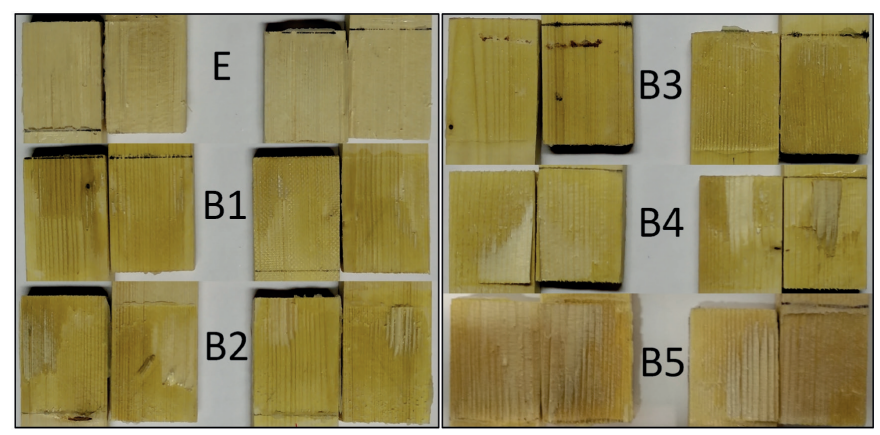

Fig. 8 Typical failure surfaces of specimens are air-dry condition at room temperature

8. ábra Próbatestek jellemzö tönkremeneteli felületei légszáraz, normál hömérsékletú esetben

It can be seen in Fig. 7 that the line drawing of the connection surface with the binder $\mathrm{E}$ is more even, the cross-sectional thickness of the clear binder is smaller than in the case of the adhesive B2, the boundaries are blurred because it penetrates well into the nearby pores of the wood surface. In contrast, binder B2 has rough line drawing and variable-thickness layer, sometimes significantly thicker than binder E (despite the same 
amount of adhesive and pressing force applied). The reason for the rough line drawing and the contact surface is that the silicate adhesive contains inadequately dissolved portions of modifying material that penetrates in the surface and closing accordingly less evenly distributed. Increasing the binder layer thickness increases the chance of material defect sites appearing in the adhesive, making it more likely to result in a weaker contact strength. Microscopic images show that binder B6 could be applied to the surface in a thinner and more uniform layer, which is in line with the higher shear strength measured.
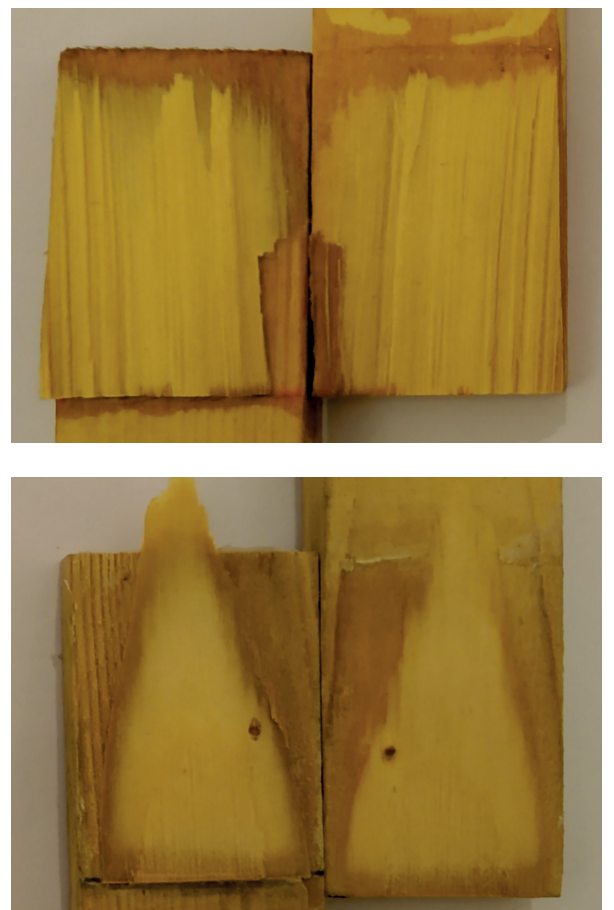

Fig. 9 B6 adhesive failure surfaces in air-dry (above) and wet condition (below) at room temperature

9. ábra A B6 jelü ragasztó tönkremeneteli felületei légszáraz (fent), illetve nedves (lent) normál hömérsékletü esetben

The comparison of the internal structure is also instructive. The inner part of the binder $\mathrm{E}$ is solid and crack-free, while B2 is cracked and in some places detached from the surface. One of the reasons for these phenomena is shrinkage, which, due to the rigid nature of the material causes cracks, the other is the rigid behaviour during loading. The B6 typically contained fewer cracks (than other silicate binders) in the binder crosssection after failure, so the effect of shrinkage was reduced and the ductility of the material increased. It is important to note that the ductility of the adhesives increased steadily with each additional silicate adhesive mixture, but this accompanied only in two cases by an increase in strength (B2 and B6). When using the silicate binder, the structural joint is usually mechanical rather than chemical. The shear teeth are not sufficiently dense and / or sized, and the joint will quickly shear along the concatenated cracks material boundary. The effect of the shear teeth was more significant, the shear stress may have increased locally, failing the near-surface layers of the timber.

In the experiments, the joints bonded with the B2 binder achieved $62 \%$ of the strength of the joints formed with the PVA binder, which means this material is not an alternative of PVA under normal conditions of use. However, the B6 has already reached $75 \%$ of the strength of the PVA binder, which is forward-looking in the case of silicate adhesives. Future research should improve the flexibility of silicate adhesives and reduce their viscosity to penetrate deeper into the pores near the surface. The development of these properties can positively affect the shear strength of the joints tested in dry condition.

\subsubsection{Moisture load at room temperature}

After moistureloading, the specimens were examined prepared with binder E, B1, B2 and B6. The integrity of adhesives E, B2 and $\mathrm{B} 6$ was maintained after moisture loading, adhesive $\mathrm{B} 1$ was completely dissolved during soaking, so the bond could not be loaded. The shear strength results of the joints made with binder $\mathrm{E}$ and $\mathrm{B} 2$ got closer significantly to each other. While in the dry case, B2 reached only $62 \%$ of the reference adhesive strength in the wet case, this ratio was 115\% (Fig. 11). The adhesives E and B2 softened, which did not cause failure in the bonded timber surface during load, and the elements of the specimens did not separate completely, but the joints could not reach higher bond strength. The B6 adhesive behaved unexpectedly, with a lower decrease in strength than any other type of binder tested. Besides, each of the three loaded specimens has partially failed in inside the timber. It should be noted that this mixture achieved $250 \%$ of the strength of the reference adhesive. Moisture and subsequent drying slightly increased the number of cracks in the bonding cross-section (Fig. 12). Thus, in the wet case, the modified silicate-based adhesive performed better although the potassium silicate adhesive containing no modifying agent was completely dissolved and thus could not be tested. It can be stated that the added modifier significantly increases the stability of the raw material against water and, as we have seen in the results of dry loading, the strength also increases. Worthy of note reference adhesive is waterproof according to the EN 205, but this standard requires 7 day of dry storing after moisture load and before the test. The examined case is different.

\subsubsection{Heat load under dry condition}

Tests under heat load were implemented on the joints formed with binder E, B1, B2 and B6. After six hours of heat exposure at $120^{\circ} \mathrm{C}$, all four types of adhesives maintained their integrity. Binder E reacted unfavourably to the elevated temperature, its strength decreased to $10 \%$ of its original value (compared to the normal temperature air-dry case) (Fig. 13). Its failure was a deformation rather than a strength failure, the bond surfaces slipped over each other, but the contact of the elements did not discontinue. After the stress exceeded the yield strength, the bonded surfaces began to slip, and the tension dropped and then continued to decrease as the area of the sheared surface decreased. This is a significant difference from the normal temperature case where there was no plasticisation. The bonded wooden surfaces are not damaged.

Adhesives B1, B2, and B6 lost their crystal water due to the high temperature (which can be seen from the adhesive discolouration), resulting in a decrease in inner strength (Fig. 13). As a result of the water loss, further shrinkage took place in the adhesive, which increased the number of microcracks, which could be more easily joined into macro cracks. However, 

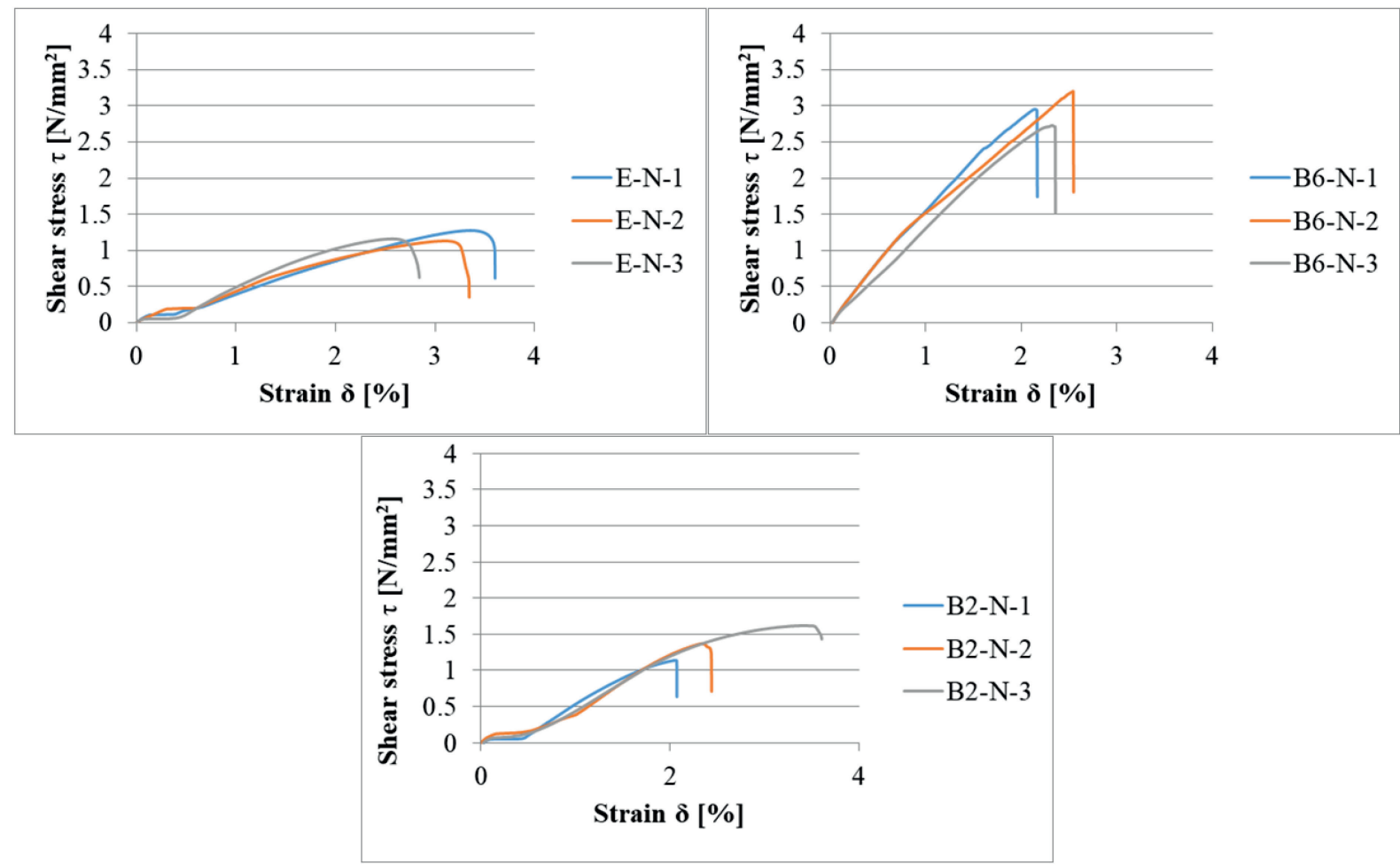

Fig. $10 \tau$ - $\delta$ diagram of adhesives $E$ (top left), B6 (top right) and B2 (below) after moisture loading

10. ábra AzE (balra fent), B6 (jobbra fent) és B2 (lent) jelü ragasztók $\tau$ - $\delta$ diagramja nedvességterhelés után

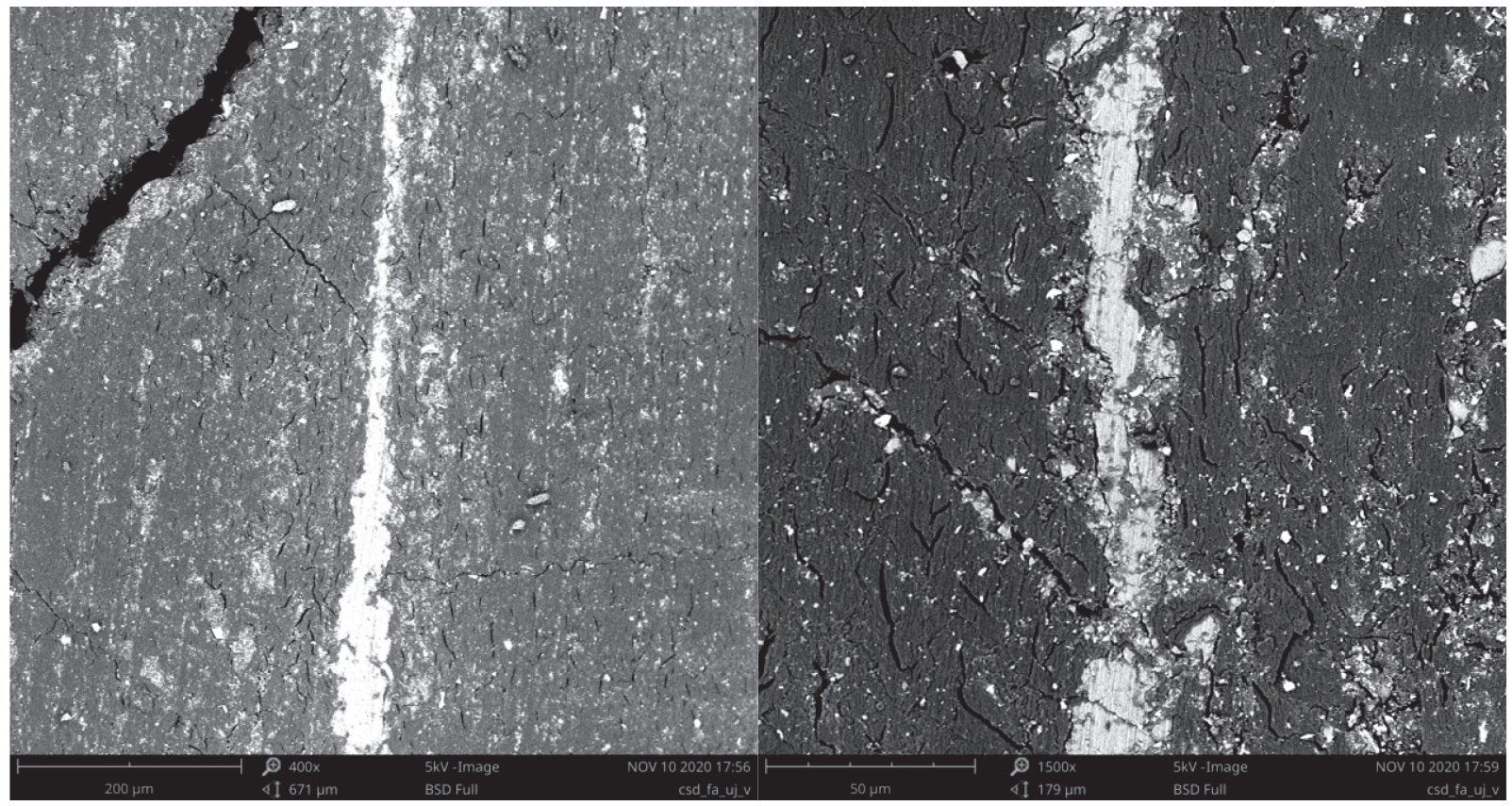

Fig. 11 The cross-section of adhesive B6 after moisture loading captured with SEM

11. ábra A B6 jelü ragasztó keresztmetszetének elektronmikroszkópos felvétele nedvesség terhelés után.

the ductility of the joint increased at a higher rate than the strength decreased. The strength of almost all silicate adhesives decreased to about $90 \%$, compared to the normal temperature air-dry case. The failures happened inside the wooden crosssection in the case of almost every silicate-based adhesives, so the adhesion between the binder and the timber was strong. Compared to adhesive B1, the heat resistance of adhesives B2 and $\mathrm{B} 6$ did not decrease with the addition of modifiers.

\subsection{Solubility test}

The strength of PVA adhesives temporarily decreases under the influence of moisture until they dry again but do not dissolve in water. Thus, the solubility test was done with a comparison of three silicate-based adhesives, one of the pure potassium silicate (B1) from which the other adhesives were mixed, and the other two modified versions of it that performed best among the inorganic adhesives in the strength tests $(\mathrm{B} 2, \mathrm{~B} 6)$. 

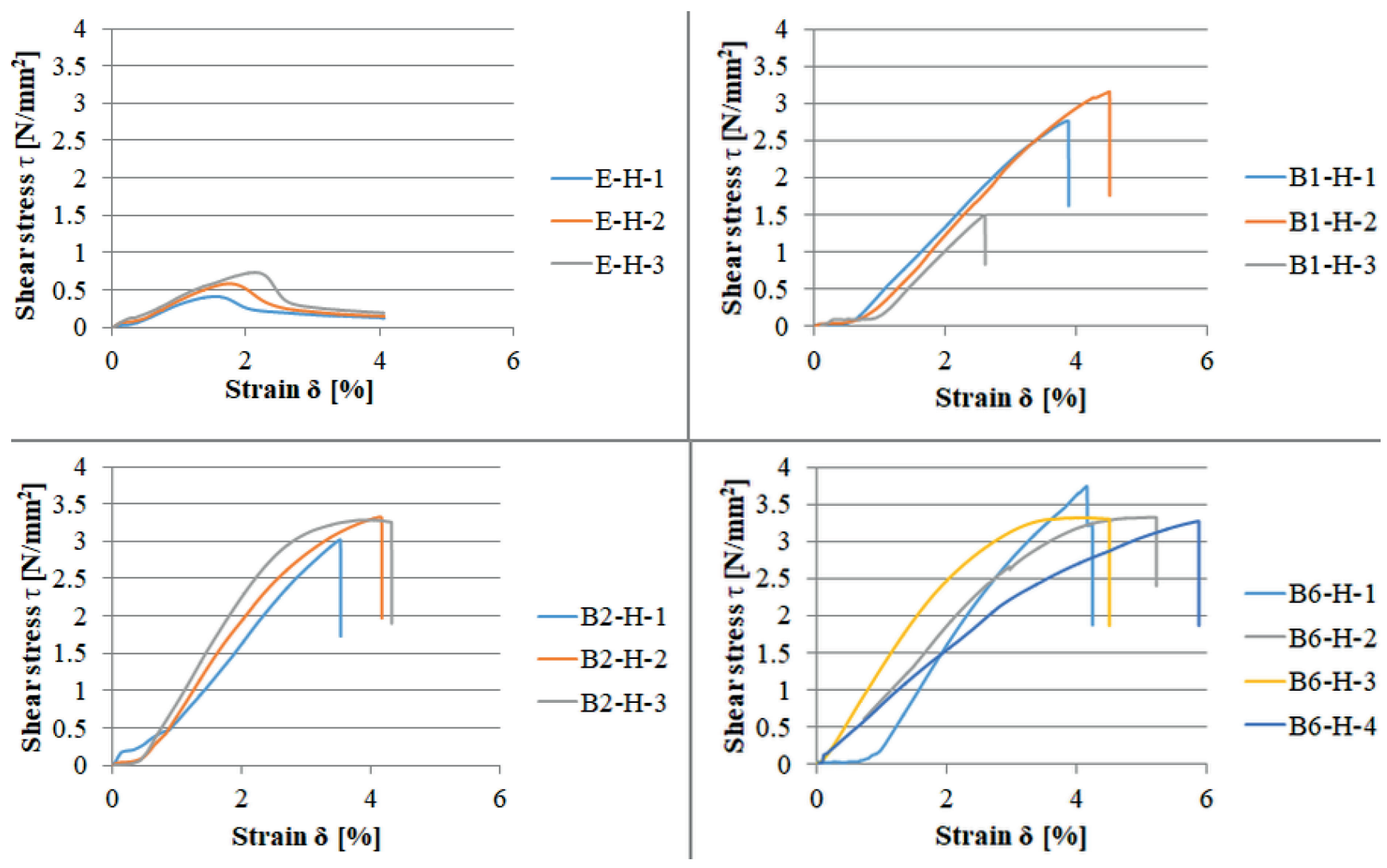

Fig. $12 \tau$ - $\delta$ diagram of binders $E$ (top left), B1 (top right) B2 (bottom left) and B6 (bottom right) during heat load

12. ábra AzE (balra fent), B1 (jobbra fent) B2 (balra lent) és B6 (jobbra lent) jelü ragasztók höterhelés közbeni $\tau$ - $\delta$ diagramja
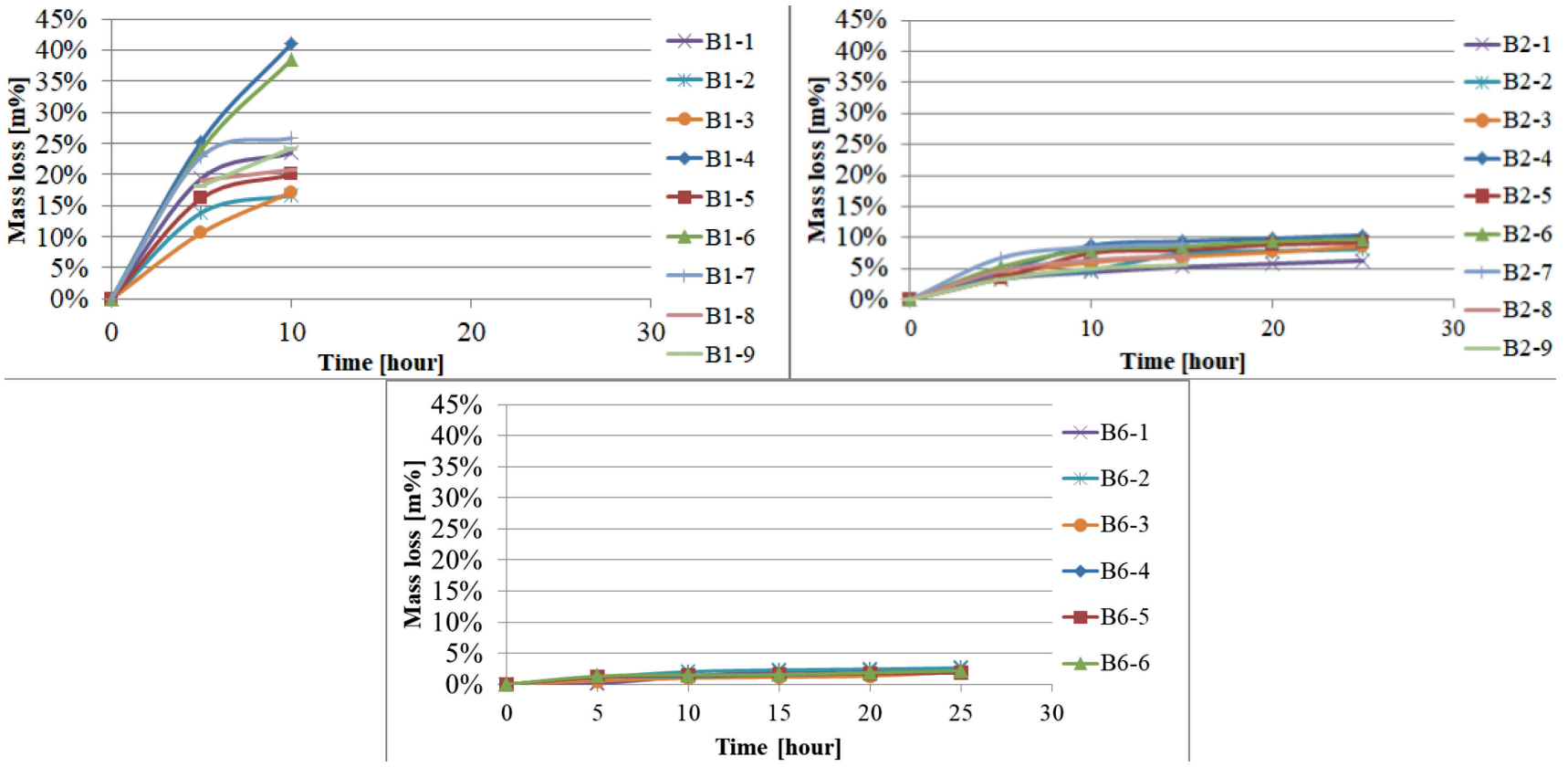

13. ábra A B1 (fent balra), B2 (fent jobbra) és B6 (lent középen) jelü ragasztók tömegvesztesége desztillált vízben való oldás során

Fig. 13 Weight loss of binders B1 (top left), B2 (top right) and B6 (bottom centre) on dissolution in distilled water

Pure potassium silicate adhesive could be tested in two cycles because, during the drying phase of the second cycle, all of the B1 samples lost their integrity. The reason for this can be seen from the mass loss-dissolution time diagram. A specimen lost more than $40 \%$ of its mass by the end of the second dissolution cycle (Fig. 13). On average, the B1 specimens had a $26 \%$ mass loss by this time. It can be clearly seen that the variance of the results is relatively large, so the material quality of the adhesive was not good even.

For the modified B2 binder, the dissolution was repeated in five cycles. Here a much lower mass loss was measured as a result of the unit-time dissolution, and the specimens maintained 
their integrity well. On average, the specimens lost $7 \%$ of their mass by the end of the last dissolution cycle (Fig. 13). It is worthy of note that the variance of the results is much smaller than for the B1 adhesive. Also, the proportion of dissolved potassium silicate decreases with an increasing number of cycles. From this, it can be concluded that the modifying agents are not completely homogeneously distributed in the sample but are present in a higher proportion in the inner parts of the cross-section. Here, the binder is properly stabilised, and the solubility of the binder increases as it moves away from the core. Once the more soluble outer layer dissolves, the mass of the binder is stabilised. The mass loss of the binder B6 also decreased compared to $\mathrm{B} 2$, and the material quality became even more uniform, as shown in Fig. 14. It is found that the outer shell is more soluble compared to the inner core.

\section{Summary and conclusions}

The research investigated the possibility of improving the properties of inorganic binders to approximate the strength of joints with PVA adhesives widely used in the wood industry today. Also, it was a priority to avoid the reduction of heat and water resistance of silicate adhesives. For this reason, the potassium silicate binder was modified with various other silicate-based materials as well as acids and alkalis. The shear strength properties of the silicate binders and the effect of the modifiers were investigated by forming bonded timber specimens, and shear strength was tested. Based on the experiments, the following conclusions can be drawn:

- Silicate adhesive cannot exceed the strength of organic polymer material under normal conditions. Silicate binder B6 achieved 75\% of the shear strength of the joint formed with the reference adhesive, and binder B2 achieved 63\%. The other silicate-based mixture performed significantly worse.

- Modifiers of silicate binder improve ductility and shear strength in small doses (B2, B6), but this phenomenon can be reversed (B3, B4). Overall, the ductility of the material increased to $225 \%$, and its strength increased to $125 \%$ compared to the pure silicate adhesive used as a reference.

- It was a seemingly contradictory phenomenon that lower strength silicate binder mixtures (e.g., adhesive B5) caused a partial proportion of partial failure in the cross-section of the timber elements of the specimens. An explanation for this was found in the cross-sections examined by SEM. Silicate binders make an uneven bonding surface and, in some locations, dense shear teeth at the micro-level in the timber surface, causing local stress increases in the joint. Because of this, the failure happened in the timber material.

- Under the influence of moisture load, the shear strength results of binders E, B6 and B2 approached each other but decreased. The strength of the silicate adhesive B6 and B2 exceeded that of the PVA adhesive. $\mathrm{B} 2$ reached $115 \%$ and the adhesive B6 250\% of the reference adhesive strength, so the used modifier can improve the water-resistance of the bonded joint.
- Under heat load, the strength of the PVA binder is significantly reduced. Timber joints showed deformation partly and partly strength failure, plastic behaviour appeared, while this was not observed at room temperature. The strength of the binder B2 and B6 decreased slightly because the silicate adhesive lost its crystal water due to the heat load, which increased the internal cracking of the adhesive.

- Under heat load, the shear strength of the bonded timber joint with modified silicate adhesive was higher than of PVA adhesive tested as a reference.

- Dissolution tests (B1, B2, B6) have shown that the addition of modifiers significantly reduces the solubility of potassium silicate and makes the material quality more uniform. Uniform material property, is not fully ensured within the cross-section, the modifying agents are oriented towards the inner layers/core of the sample and its stabilising effect appears here.

B2 and B6 performed better under moisture and heat load than the commonly used PVA binder among the silicate binders. Based on experimental results, it was stated that with modifiers, we could create an inorganic binder with a lower environmental footprint that is competitive with the binders currently used in structural timber elements.

\section{References}

[1] P. Glos, Holz - Potentiale des nachhaltigen Baustoffes, Informationsdienst Holz, 2008. https://informationsdienst-holz.de/fileadmin/ Publikationen/3_Spezial/Spezial_Potenziale_des_nachhaltigen_ Baustoffes_2008.pdf (accessed Feb. 07, 2020).

[2] Unece \& Fao, (1944):, Forest products, Nature, vol. 153, number 3892, pp. 689-690, ISSN:00280836, ISBN:978-92-1-117081-8, https://doi.org/10.1038/153689a0.

[3] O. Ülker, Wood Adhesives and Bonding Theory. InTech, (2016):

[4] N. D. Lamontagne, (2014):, Making polyurethane foams more sustainable: Sustainability's a heavy topic even when talking about lightweight, energyefficient PUR foams, Plastics Engineering, vol. 70, number 6, pp. 24-26, ISSN:00919578, https://doi.org/10.1002/j.1941-9635.2014.tb01190.x.

[5] Transparency Market Research, Wood Adhesives and Binders Market - Global Industry Analysis 2014 - 2020, 2014. http://www. transparencymarketresearch.com/wood-adhesives-binders-market.html (accessed Jan. 13, 2020).

[6] E. Norström, D. Demircan, L. Fogelström, F. Khabbaz, and E. Malmström, (2018):, Green Binders for Wood Adhesives, Applied Adhesive Bonding in Science and Technology, doi: 10.5772/intechopen.72072.

[7] A. Pizzi, K. Mittal, and F. Keimel, (2003):, Historical Development of Adhesives and Adhesive Bonding, Handbook of Adhesive Technology, Revised and Expanded, https://doi.org/10.1201/9780203912225.pt1.

[8] I. Skeist, (1977):, Handbook of adhesives., ISSN:00160032, https://doi.org/10.1016/0016-0032(62)90851-7.

[9] I. Skeist and J. Miron, (1990):, Introduction to Adhesives, Handbook of Adhesives, pp. 3-20, doi: 10.1007/978-1-4613-0671-9_1.

[10] A. NITTHIYAH, (2013):, Optimization and Characterizationof Melamine Urea Formaldehyde (Muf) Based Adhesive With Waste Rubber Powder (Wrp)As Filler.

[11] G. Zeppenfeld, (1991):, Klebstoffe in der Holz- und Möbelindustrie, pp. 49-51, ISBN:3871813591.

[12] M. L. Selbo, (1975):, ADHESIVE BONDING OF WOOD., Tech Bull US for Serv.

[13] U. Müller, S. Veigel, and J. Gabriel, (2009):, Performance of One Component Polyurethane in Comparison to Other Wood Adhesives, International Conference on Wood Adhesives 2009, pp. 196-202, doi: 9781617389863 
[14] G. Zeppenfeld, (1991):, Klebstoffe in der Holz- und Möbelindustrie, pp. 49-51, ISBN:9783871813597.

[15] A. Messmer, (2015):, Life cycle assessment (LCA) of adhesives used in wood constructions, number May, pp. 48, XXXI, [Online]. Available: https://www.researchgate.net/publication/279286317_Life_cycle_ assessment_of_adhesives_used_in_wood_constructions.

[16] S. Cass, (1961):, A comparison of hot press interior plywood adhesives, Journal of Natural Products, vol. 11, pp. 285-287.

[17] M. L. Selbo, (1975):, Adhesive Bonding of Wood., Tech Bull US for Serv, number 1512.

[18] X. Zhang, Q. Chen, and J. Wang, (2016):, Optimization of conditions for preparation of poly (vinyl alcohol)-water glass adhesive by response surface methodology, https://doi.org/10.2991/icadme-16.2016.51.

[19] P. Peng, X. Zhou, and J. Ma, (2011):, Water glass compound starch used as surface sizing agent to improve the strength of linerboard, BioResources, vol. 6, number 4, pp. 4158-4167, ISSN:19302126, https://doi.org/10.15376/biores.6.4.4158-4167.

[20] F. A. Kamke and J. N. Lee, (2007):, Adhesive penetration in wood A review, Wood and Fiber Science, vol. 39, number 2, pp. 205-220, ISSN:07356161.

[21] T. Czvikovszky, P. Nagy, and J. Gaál, (2000):, A polimertechnika alapjai, pp. 1-453, ISBN:963-420-621-2.
[22] O. Ülker, Wood Adhesives and Bonding Theory. (2016):

[23] I. Gavrilović-Grmuša, M. Dunky, M. Djiporović-Momčilović, M. Popović, and J. Popović, (2016):, Influence of pressure on the radial and tangential penetration of adhesive resin into poplar wood and on the shear strength of adhesive joints, BioResources, vol. 11, number 1, pp. 2238-2255, ISSN:19302126, https://doi.org/10.15376/biores.11.1.2238-2255.

[24] M. S. Testület, (2017):, MSZ EN 205:2017: Adhesives. Wood adhesives for non-structural applications. Determination of tensile shear strength of lap joints.

[25] L. Szentes, (2018):, A rövid idejü intenzív csapadékok statisztikai vizsgálata, pp. 56-60.

[26] W. Conshohocken, (2010):, Standard Test Method for Strength Properties of Adhesives in Two-Ply Wood Construction in Shear by Tension Loading 1, Library, vol. 98, number April 2004, pp. 12-14.

Ref.:

Csanády, Dániel - Fenyvesi, Olivér : Shear behaviour of silicate-based structural adhesives for timber

Épitőanyag - Journal of Silicate Based and Composite Materials, Vol. 73, No. 2 (2021), 72-82. p. https://doi.org/10.14382/epitoanyag-jsbcm.2021.12
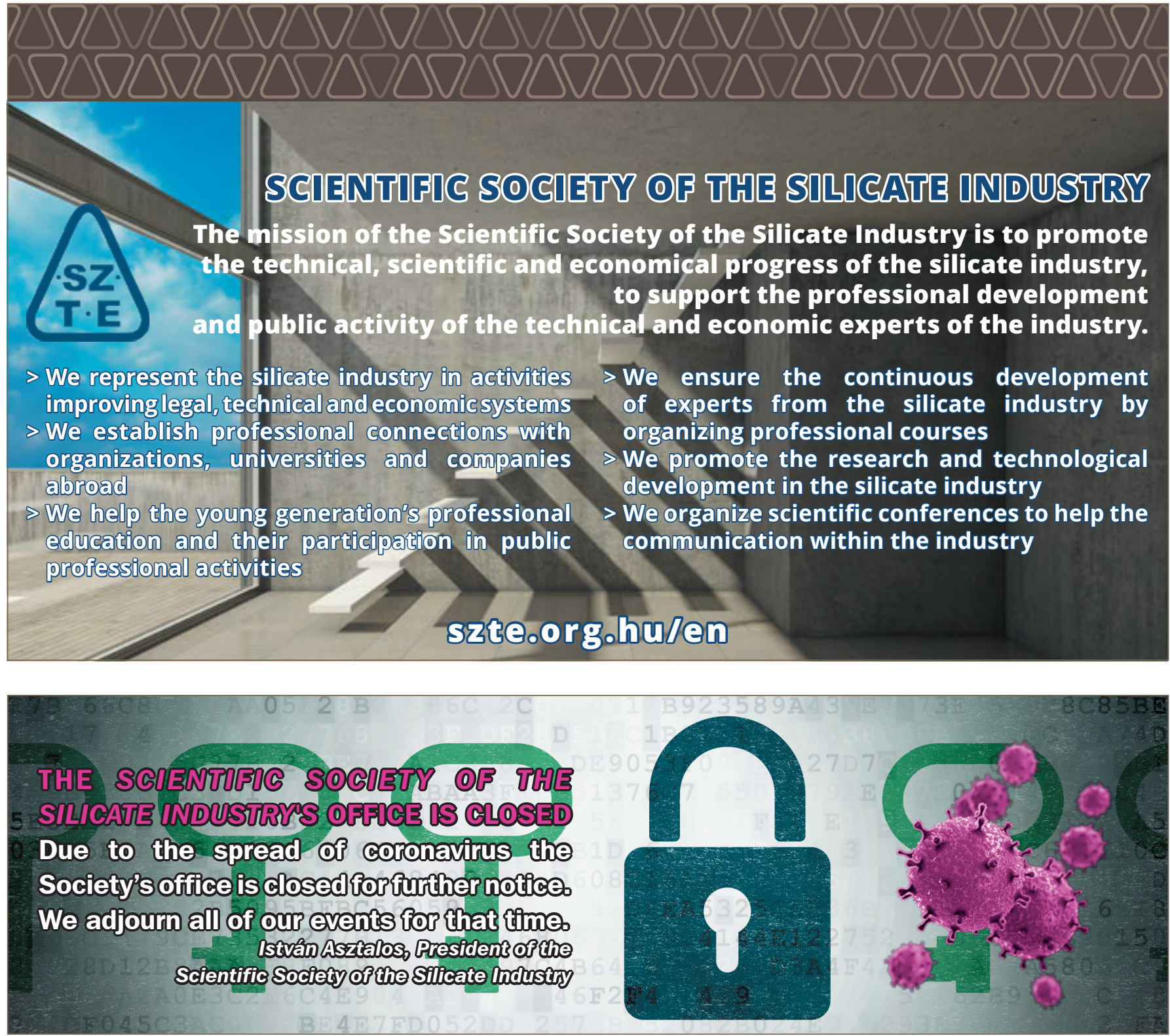